\title{
Transatlantica
}

Revue d'études américaines. American Studies Journal

\section{American Women Writers Abroad: Myth and Reality}

\section{Stéphanie Durrans}

\section{(2) OpenEdition}

\section{Journals}

Electronic version

URL: https://journals.openedition.org/transatlantica/12412

DOI: $10.4000 /$ transatlantica. 12412

ISSN: 1765-2766

\section{Publisher}

Association française d'Etudes Américaines (AFEA)

\section{Electronic reference}

Stéphanie Durrans, "American Women Writers Abroad: Myth and Reality", Transatlantica [Online], 1। 2018, Online since 10 September 2019, connection on 31 January 2023. URL: http://

journals.openedition.org/transatlantica/12412 ; DOI: https://doi.org/10.4000/transatlantica.12412

This text was automatically generated on 31 January 2023.

\section{(c)}

Creative Commons - Attribution-NonCommercial-NoDerivatives 4.0 International - CC BY-NC-ND 4.0

https://creativecommons.org/licenses/by-nc-nd/4.0/ 


\title{
American Women Writers Abroad: Myth and Reality
}

\author{
Stéphanie Durrans
}

Be they explorers, adventurers, travellers, exiles or expatriates, scores of women have broken free from the domestic sphere to which a male-dominated society would have them bound and recorded their impressions of the wider world in their writings or used them as artistic material. For a long time, though, British Victorian women's literature remained the almost exclusive focus of critical inquiry while American women writers' contribution to this field was by and large neglected. ${ }^{1}$ This gap in the existing scholarship has been filled over the years by a number of compelling studies which have brought to light specific paradigms of female mobility in a U.S. context. Most of these studies understandably addressed the question within the time frame of the long nineteenth century, when the development of modern means of transportation allowed for extensive travelling across land and sea. This was also a time when the U.S. was struggling to assert its difference from European superpowers and establish itself as a full-fledged nation. As a result, no study of women's travel texts in the nineteenth century can afford to neglect the intertwined questions of selfhood and nationhood-and the first four essays included in this collection are no exception to this rule. They also show women trying to navigate their way between the two extremes highlighted by Elsden:

Mainstream, nineteenth-century constructions of White femininity seemed to limit male portrayals of women abroad to two categories: the assertive "feminist," whose forthrightness as a person and an American signify as "masculine," and the hyperfeminine lady, whose superficiality trivializes her as a non-threatening diversion. (xxiv)

The next three essays focus on a heterogeneous group of twentieth-century women writers whose experience abroad led them to uncover the darker sides of their own selves or of human nature in general-from childhood traumas to a confrontation with evil and a state of utter disarray when faced with the impossibility to relate to any place. 
2 The contributors to this special issue ${ }^{2}$ build on previous studies by established scholars like Mary Suzanne Schriber, Amy Kaplan, and Susan L. Robertson, ${ }^{3}$ to name but a few, to examine the complex ways in which American women travelers have approached the question of otherness while seeking to understand how these women's travel experience contributed to reshaping their identities and how it helped them negotiate gender expectations. For many of them, like Marsh and Bishop, translation plays a key role in this process. In Mulberry and Peach though (a late twentieth-century novel written in Chinese by a Chinese-American author), the protagonist stands out as one of those modern-day migrants whose impossibility to create connections with either their home or their host country condemns them to remain lost in translation. "Remain / lost," to borrow the phrase used by Myriam Bellehigue as a coda to her essay, nicely encapsulates the tension between presence and absence, between memory and oblivion, as well as between stasis and motion for some of these wanderers.

3 The following essays focus on a variety of texts, ranging from the more traditional travel accounts and so called "ego-documents" (i.e. memoirs, private correspondence, etc.) to the reading lists of women's associations, to illuminate the ideological dimension underlying the works under study. Farnham travelled to California at a time when it was still a Western territory; Alcott to France and Italy; Marsh to Italy and Turkey; WRTA members to England, France, and Italy for the most part; Porter to Germany; Bishop to Brazil; and Hualing Nieh from China to the U.S., bringing us back full circle to the beginning of our journey-or not quite on account of the inconclusive nature of Mulberry/Peach's "translation" process. Such a broad geographical scope allows exploration of a variety of experiences and approaches to the foreign element in their texts.

4 The first two essays in this collection feature writers who articulate a critique of separate spheres and women's domestic confinement in sharply differing ways. Farnham's account of her eventful journey to the rugged frontiers of civilization in 1849 could be expected to provide a welcome corrective to official male-centered narratives of expansion, adventure, or colonization in the Wild West, but the epic dimension of the first half soon gives way to a more factual, impersonal approach. These sharp structural contrasts point at possible divisions within her own self which, in their turn, might suggest a tension between subject and object, i.e. between the desire to project herself as an adventuress type and the need to step back and retreat behind a more conventional, self-effacing account that would not undermine social expectations of gender roles. Claire Sorin shows how, in Farnham's view, feminizing California paved the way for the development of democratic institutions since women would be the ones to deliver the state from corruption and degeneracy. In doing so, Farnham championed the ethos of "Manifest Domesticity," a concept which allowed critic Amy Kaplan to conflate the rhetorics of domesticity and Manifest Destiny since both of these "share a vocabulary that turns imperial conquest into spiritual regeneration in order to efface internal conflict or external resistance in visions of geopolitical domination as global harmony" (588). At the same time, however, domestic discourse "both redresses and reenacts the contradictions of empire through its own double movement to expand female influence beyond the home and the nation while simultaneously contracting woman's sphere to police domestic boundaries against the threat of foreignness both within and without" (Kaplan 585). Although, at this early stage of her writing career, Farnham does not quite manage to resolve these many 
contradictions, the book does foreshadow the development of more radical views that she would expound a few years later in Woman and her Era.

5 Inversely, the transgression of geographical borders does appear to allow for more gender fluidity in Alcott's unfinished novella Diana and Persis. Leslie Hammer shows how Alcott playfully undermined and reversed the polarity Old World / New World by transforming the U.S. itself into the Old World and praising Europe as a land where American women could throw off the shackles of domesticity and break free of their culture's patriarchal ideology. In many ways, however, Alcott's novella simultaneously reinforces the boundaries that it seeks to transcend. Hammer's perceptive reading shows how, far from undermining the nation-building rhetoric of the U.S. as well as conventional constructions of race and citizenship, Alcott's feminist agenda is predicated upon foreign exploitation and subjugation of the dark-skinned Other. Reformist views thus combine with ethnocentrism in this highly complex sentimental novella. ${ }^{4}$

6 The same ambivalence between progressive and conservative views permeates the reading lists provided by the Women's Rest Tour Association (WRTA) to the thousands of American women who set off for Europe at the turn into the twentieth century. While the WRTA promoted women's education, featured numerous women writers in its bibliographies, and encouraged their members to travel independently by providing them with all the advice they needed on their journeys across Europe, Julia Carson shows that it also manifested a clear nationalist bias in favor of Boston's cultural authority and of English connections. Class and ethnic prejudices are also in evidence in the WRTA's emphasis on the picturesque in the depiction of the local populations as well as in the absence of any book addressing more controversial social or political concerns.

7 Caroline Crane Marsh's experience in Italy and Turkey, Etta Madden reports, reveals an altogether different approach to cultural negotiation as she became involved in social reform movements in the countries where she stayed. The tension between preserving traces of "the foreign" and absorbing it into some sort of universal essence consequently informs her work as a translator. Like Martha Bayard before her (see Schriber 1994 84), Caroline Crane Marsh was one of those diplomats' wives who followed their husbands abroad but in her case contact and interaction with the local population served less to promote the imperialistic ventures of her home nation than to foster the emergence of a new, self-assertive woman whose work was recognized for its intrinsic value.

8 Unlike those of Caroline Crane Marsh, Elizabeth Bishop's translations from Brazilian texts do not foreground the intersections between the intimate and the political. Instead, they served as a catalyst for a very personal investigation into the poet's past and the intricate workings of memory and oblivion. Bishop even appropriated these translations by incorporating them within her own collections of prose and poetry. What could have been construed as an escape from confrontation with oneself actually turned into a path to self-knowledge. As noted by Terry Caesar, "Americans have not historically experienced travel abroad as a displacement but as a replacement-and then either a return or a reinscription" (68).

9 As was the case for Bishop, a chance happening led Katherine Anne Porter to spend some time in a country which was not her initial destination. Instead of investigating Porter's well-known connections with Mexico, Joseph Kuhn has chosen to focus on a 
little-known episode in Porter's life and on its reverberations throughout her work. Porter's five-month stay in Weimar Germany was a veritable eye-opener which led her to reflect upon the nature of evil and to develop a conception of "negative evil" that bears striking affinities with Hannah Arendt's "banality of evil." In both authors' works, memory once more plays a vital part in countering the devastating effects of irresponsibility and carelessness. Unlike Farnham and Alcott, for instance, Porter is not concerned with articulating a feminist perspective. Instead, her experiences abroad prompted an inquiry of a more metaphysical order while bringing her closer to a philosopher with whom she appeared to have little in common and leading her to develop a modernist aesthetics that could best capture the dramatic political transformations underway.

10 Away from the exclusive white, middle-class focus that characterizes the first six women under study, Grazia Micheli explores the potentially negative impact of transnationalism when emigrants end up in a perpetual condition of exile, be it linguistic, political or cultural. Travelling obviously has altogether different implications for a Chinese immigrant than it does for the more affluent middle or upper classes of American society. In Mulberry and Peach, the Chinese-American writer Hualing Nieh goes even further than Porter in experimenting with form and language. Her heroine finds no release from the constraints of patriarchy or female oppression in the U.S. The twin experience of dislocation and "attempted relocation" that characterizes Eliza Farnham in Sorin's reading is one that the heroine of Mulberry and Peach will never carry through, doomed as she is to remain stranded in a terrifying inbetween which complicates our understanding of transnationalism. In Mulberry and Peach, Hualing Nieh refutes accepted views of the transnational as likely to counter hegemonic discourses, views that the American historian of Chinese descent Mae M. Ngai expressed most forcefully when she seconded Shelley Fisher Fishkin's call for a transnational turn in American studies and claimed that "[a] focus on the transnational, with its emphasis on multiple sites and exchange, can potentially transform the figure of the 'other' from a representational construct to a social actor" (60). Instead, Nieh's protagonist finds in travel no source of agency, self-knowledge, uplift or empowerment-only confusion and turmoil.

11 The roughly chronological order in which the following papers have been arranged allows us to witness the gradual deconstruction of the myth of the journey by women writers who, for their most part, chose not to follow the beaten tracks of travel literature. The present collection, albeit limited in its format, provides a composite view of how American women have engaged with travelling and transnational issues since the middle of the nineteenth century and it will hopefully enable readers to appreciate more fully the complexities of a shape-shifting genre in which the dark dynamics of power and appropriation are played out against a background of exciting adventures and picturesque landscapes. 


\section{BIBLIOGRAPHY}

BIRKETT, Dea. Spinsters Abroad: Victorian Lady Explorers. Oxford: Blackwell, 1989.

BOHLS, Elizabeth A. Women Travel Writers and the Language of Aesthetics, 1716-1818. Cambridge: Cambridge University Press, 1995.

CAESAR, Terry. Forgiving the Boundaries: Home as Abroad in American Travel Writing. Athens: The University of Georgia Press, 1995.

COSCO, Joseph P. Imagining Italians: The Clash of Romance and Race in American Perceptions, 1880-1910. Albany: SUNY Press, 2012.

ELSDEN, Annamaria F. Roman Fever: Domesticity and Nationalism in Nineteenth-Century American Women's Writing. Columbus: the Ohio State University Press, 2004.

FISH, Cheryl J. Black and White Women's Travel Narratives: Antebellum Explorations. Gainesville: University Press of Florida, 2004.

FISHKIN, Shelley Fisher. "Crossroads of Cultures: The Transnational Turn in American Studies: Presidential Address to the American Studies Association, November 12, 2004." American Quarterly, vol. 57, no. 1, 2005, p. 17-57.

GHOSE, Indira. Women Travellers in Colonial India: The Power of the Female Gaze. Oxford: Oxford University Press, 1998.

GREWAL, Inderpal. Home and Harem: Nation, Gender, Empire, and the Cultures of Travel. Durham, NC: Duke University Press, 1996.

KAPLAN, Amy. “Manifest Domesticity.” American Literature, vol. 70, no. 3, 1998, p. 581-606.

McEWAN, Cheryl. Gender, Geography and Empire. Victorian Women Travellers in West Africa. Leicester: Ashgate, 2000.

NGAI, Mae M. “Transnationalism and the Transformation of the 'Other': Response to the Presidential Address.” American Quarterly, vol. 57, no. 1, 2005, p. 59-65.

ROBERTSON, Susan L. Antebellum American Women Writers and the Road: American Mobilities. New York: Routledge, 2011.

RUSSELL, Mary. The Blessings of a Good Thick Skirt: Women Travellers and Their World. London: Collins, 1986.

SCHRIBER, Mary S. "Assuming a Public Voice: The Travel Writing of Margaret Fuller and Harriet Beecher Stowe." Femmes de conscience : Aspects du féminisme américain (1848-1875). Eds. Daniel Royot and Susan Goodman. Paris: Presses Sorbonne Nouvelle, 1994, p. 127-148.

SCHRIBER, Mary S. Writing Home: American Women Abroad, 1830-1920. Charlottesville: University Press of Virginia, 1997.

STEADMAN, Jennifer B. Traveling Economies: American Women's Travel Writing. Columbus: Ohio State University Press, 2007.

STEVENSON, Catherine B. Victorian Women Travel Writers in Africa. Boston: Twayne's English Author Series, 1992. 


\section{NOTES}

1. See, for instance, Dea Birkett's Spinsters Abroad: Victorian Lady Explorers, Elizabeth A. Bohls's Women Travel Writers and the Language of Aesthetics, 1716-1818, Indira Ghose's Women Travellers in Colonial India: The Power of the Female Gaze, Inderpal Grewal's Home and Harem: Nation, Gender, Empire, and the Cultures of Travel, Cheryl McEwan's Gender, Geography and Empire. Victorian Women Travellers in West Africa, Catherine Barnes Stevenson's Victorian Women Travel Writers in Africa, and Mary Russell's The Blessings of a Good Thick Skirt: Women Travellers and Their World, all of which were published in the 1980s and 1990s.

2. The essays in this volume were largely though not entirely selected from those presented at the 2017 Society for the Study of American Women Writers International Conference. The conference was held at the Université Bordeaux Montaigne, France, from July 5 to July 82017 on the subject of "Border Crossings: Translation, Migration, \& Gender in the Americas, the Transatlantic, \& the Transpacific."

3. In addition to Mary Suzanne Schriber's Writing Home: American Women Abroad, 1830-1920, and Susan L. Robertson's Antebellum American Women Writers and the Road: American Mobilities, Cheryl Fish's Black and White Women's Travel Narratives: Antebellum Explorations and Jennifer Bernhardt Steadman's Traveling Economies: American Women's Travel Writing provide valuable insights into the experience of American female travelers from an intersectional perspective.

4. The contradictions inherent in the American perception of Italians as both attractive and repulsive are the focus of Joseph P. Cosco's remarkable study, Imagining Italians: The Clash of Romance and Race in American Perceptions, 1880-1910. How to reconcile visions of Italy as "the land of art, history, culture, and romance" (Cosco 22) with the distrust generated by those "hundreds of thousands of picturesque, but dirty and menacing, Italian peasants pouring into [...] New York City" (Cosco 23) was the challenge faced by late nineteenth-century Americans.

\section{AUTHOR}

\section{STÉPHANIE DURRANS}

Université Bordeaux Montaigne, Stephanie.Durrans@u-bordeaux-montaigne.fr 